\title{
C-peptide is not a simple laboratory test
}

\author{
JOSE R VILLARREAL
}

Clinical Epidemiologist and Cardiovascular Risk Doctor, Universidad Autónoma de Bucaramanga, Bucaramanga, Itaguí, Colombia

We welcome
correspondence and
research letters to the
journal.
Research letters should
be no more than 800
words with a maximum
of 10 references, one
table and/or one figure.
These will usually be
short reports of interim
work or final reports of
research that do not
warrant a full research
paper publication.
Letters to the editor
relating to any articles
published in the Journal.
Letters should ideally
be submitted within two
months following
publication of the article
on which the authors
wish to comment, and
should be no more than
600 words with up to
five references

Key words: C-peptide, diabetes, therapeutic

The polypeptide molecule known as C-peptide produced by beta cells and a precursor of insulin ${ }^{1,2}$ is not a simple laboratory test to reclassify diabetes, as described in the article by Morrison et al. ${ }^{3}$ Significant clinical studies are being carried out which show that it is an active metabolite that fulfills functions with biological potential for the treatment of complications associated with diabetes, avoiding endothelial dysfunction, increasing vasodilation at the expense of nitric oxide, with a substantial decrease in the production of inflammatory chemokines and reduction in proteinuria at the renal level, as well as other in vitro evidence. ${ }^{4}$

C-peptide should be taken into account not only as a laboratory test but also as a future therapeutic option for patients with or without microvascular or macrovascular complications. This study paves the way for a more rigorous and methodological quality follow-up investigation. ${ }^{5}$ This case report outlines both a diagnostic and a therapeutic option at the same time.

\section{Conflict of interest None. Funding None.}

\section{References}

1. Pinger CW, Entwistle K, Bell TM, Liu Y, Spence DM. C-peptide replacement therapy in type 1 diabetes: are we in the trough of disillusionment? Mol Biosyst 2017;13(8):1432-7.

https://doi.org/10.1039/ C7MB00199A
2. Danne T, Kordonouri O. Use of technology to potentially preserve C-peptide in type 1 diabetes mellitus. Pediatr Endocrinol Rev 2010;7(Suppl 3):396-400.

3. Morrison AE, Sim SY, Kong M-F, Gregory R. Type 1 or type 2 diabetes: has the ship already sailed? $\mathrm{Br} J$ Diabetes 2021;21:116-9. https://doi.org/10.15277/ bjd.2021.297

4. Washburn RL, Mueller K, Kaur G, et al. C-peptide as a therapy for type 1 diabetes mellitus. Biomedicines 2021;9(3):270.

https://doi.org/10.3390/ biomedicines9030270

5. Abdel-Hamid HA, Abdel-Hakeem EA, Zenhom NM, Toni N. C-peptide corrects hepatocellular dysfunction in a rat model of type 1 diabetes. J Physiol Biochem 2020;76(3):417-25.

https://doi.org/10.1007/s13105-020-00748-y
Dear Dr Villarreal,

We agree that C-peptide may have some biological activity of its own. The case report mentions C-peptide being used to aid diagnosis of type of diabetes and not as a treatment.

Dr Marie-France Kong on behalf of the authors 